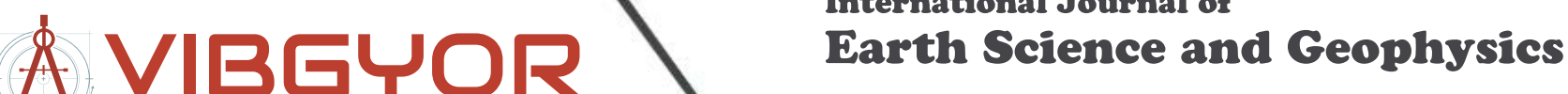

ISSN: 2631-5033

\section{New England-Morocco Connection and the Northwestern Pan-African Collision}

\author{
Patrick J Barosh ${ }^{1,2 *}$ \\ ${ }^{1}$ Chinese Academy of Geological Sciences, China \\ ${ }^{2}$ P.J. Barosh and Associates, Aaron Ave, Bristol, USA
}

\begin{abstract}
Recent independent geologic compilations of southeastern New England and the Anti-Atlas of Morocco show near identical sequences of Late Proterozoic through Ordovician lithology and events that indicate a very close connection until separated in the Mesozoic. This connection demonstrates that the Pan-African deformation in the West African Craton was governed by the Appalachian collision zone, which traverses southeastern New England, and precludes the presence of any intervening "Avalonia". The corresponding events are: early rifting initiation of the lapetus Ocean and deposition along a passive margin, $\sim 1000-750 \mathrm{Ma}$, initial subduction and island arc development with turbidic, volcaniclastic, and volcanic strata, c. 750-700 Ma, ocean basin shrinkage and thrusting with anatectic granite marking initial Pan-African collision, c. 700-640 Ma, collision and ocean basin closure with intensive deformation, batholithic granite and strong metamorphism, in the west, marking the main Pan-African Orogeny, c 630-615 Ma, alpine uplift, erosion and draining of lapetus, c 615-605, formation of basinand-range topography with volcanoes along active border faults sending debris into the terrestrial to partially marine basins followed by coarse conglomerate and finer clastic material as tectonism wanes, c 605-545 Ma, gradual filling and overtopping of basins by fine clastic and carbonate deposits followed by quartzitic sand as Rheic Sea transgresses, Early Cambrian- Early Ordovician. Later renewed convergence closed a resurrected lapetus Ocean to the west collision zone with granite forming in the zone and renewed volcanic activity along borders of the Boston Basin in the Middle-Late Ordovician. This Taconic Orogeny was a post script to the PanAfrican Orogeny, but had apparently little effect in northwest Africa and was the final welding of the Laurentian and West African plates. This history demonstrates that the plates first came together in the Late Proterozoic and were completely merged by the Late Ordovician.
\end{abstract}

\section{Keywords}

Pan-African orogeny, Southeastern new england, Anti-Atlas, Morocco, Late proterozoic, Taconic orogeny

\section{Introduction}

New England and northwest Africa were adjacent to one another prior to the opening of the Atlantic Basin (Figure 1) and it has long been noted that the early Mesozoic basins present on either side match, but correlations with earlier lithology have been elusive. Untenable hypotheses about New England geology that misplaced early orogenies into the mid Paleozoic, scattered incomplete descriptions in northwest Africa and the concept of an intervening "Avalonia" have created obstacles to correlation. Recent independent compilations of the geology of southeastern New England and the Anti-Atlas of Morocco now reveal near identical sequences of Late Proterozoic tectonic events and lithology at similar times. This close connection precludes any separate "Avalonia" and demonstrates that the plate collision zone exposed in New England controlled events in Morocco. Most rock and the major tectonic events in southeastern
New England have long been known to be Late Proterozoic in age and related to the Cadomian or Pan-African orogeny, but it has taken these new data to demonstrate the specific manner of the match across the Atlantic.

Geologic studies in New England and Maritime Canada began over two hundred years ago and the region has been blessed by many excellent geologists. Charles Lyell's 1845 [1] compiled map of the region shows the general layout with Precambrian granite and metamorphic strata in the south with progressively younger irregularly overlapping Paleozoic strata to the north-east. However, this depiction was disrupted in the 1950s when Marland Billings [2] miscorrelated unmetamorphosed terrestrial Siluro-Devonian volcanic rock and redbeds with the regionally metamorphosed and deformed marine turbidic strata a few miles away and inadvertently changed a major Late Proterozoic orogeny into a Devonian Acadian

*Corresponding author: Patrick J Barosh, Visiting Research Fellow of the Chinese Academy of Geological Sciences, China, P.J. Barosh and Associates, 103 Aaron Ave, Bristol, RI 02809, USA, E-mail: pjbarosh@fullchannel.net

Received: January 05, 2016: Accepted: August 06, 2016: Published: August 09, 2016

Copyright: (c) 2016 Barosh PJ. This is an open-access article distributed under the terms of the Creative Commons Attribution License, which permits unrestricted use, distribution, and reproduction in any medium, provided the original author and source are credited. 


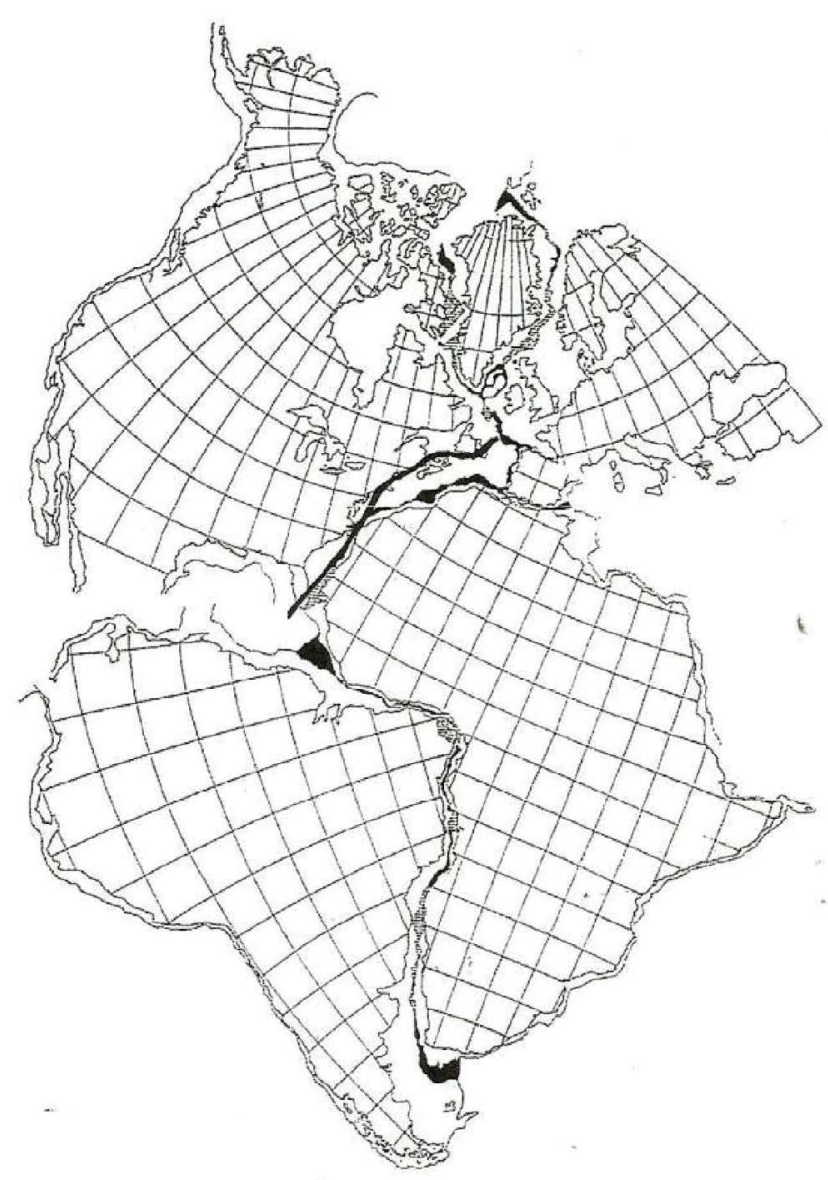

Figure 1: Map of western Pangea showing best fit of the continental plates [modified from [38]]. The heavy line marks the Appalachian collision zone that controled the western Pan-African orogeny.
Orogeny. This concept still bedevils the literature [3,4]. This was contrary to $\mathrm{CD}$ Walcott's [5] previous remarkable work that demonstrated a divide between American and European Cambrian fauna in strata that lapped up on both sides of New England. In 1966 JT Wilson [6] suggested the terranes containing these faunas were separated by a plate collision zone, which lay along the southeast side of New England and the Maritime Canada that marked a closure of a previous ocean. Wilson, in part, connected faults then being mapped by the Boston Office of the US Geological Survey across the generally good exposures of southern New England with others to the north. By 1977 it was demonstrated that the collision zone separated a profound stratigraphic, structural and geophysical break prior to the Silurian [7]. The fill of Boston Basin, which is a rift dropped into the granitic batholith east of this collision zone, had been considered to be late Paleozoic age, but then was revealed to be Late Proterozoic in age [8]. Further detailed structural, stratigraphic and geophysical studies in southern New England by the U.S.G.S. augmented by those of the US Nuclear Regulatory Commission have defined a great westdipping collision zone that snakes across the region and connects with one in Canada (Figure 2). It was then recognized here early that this zone represented the Cadomian or Pan-African Orogeny [9] and soon after in Canada [10]. In addition the matching geologic events on both sides of the collision zone show that they were deformed together in the Late Proterozoic as they collided.

The studies in southern New England, especially the detailed measured and described stratigraphic sections made systematically across the region, combined with data from geophysical studies, the extensive system of bedrock tunnels and thousands of boreholes makes southern New England the best studied by far in the eastern Appalachian Orogen. Unfortunately many investigations are unpublished. However, summaries of the southeastern New England geology have been prepared periodically since 1977 [7,9,11-14] as new discoveries were made. The later investigations clarify some Late Proterozoic stratigraphy and separate younger structure to give a better picture of the early tectonic events. Because of the

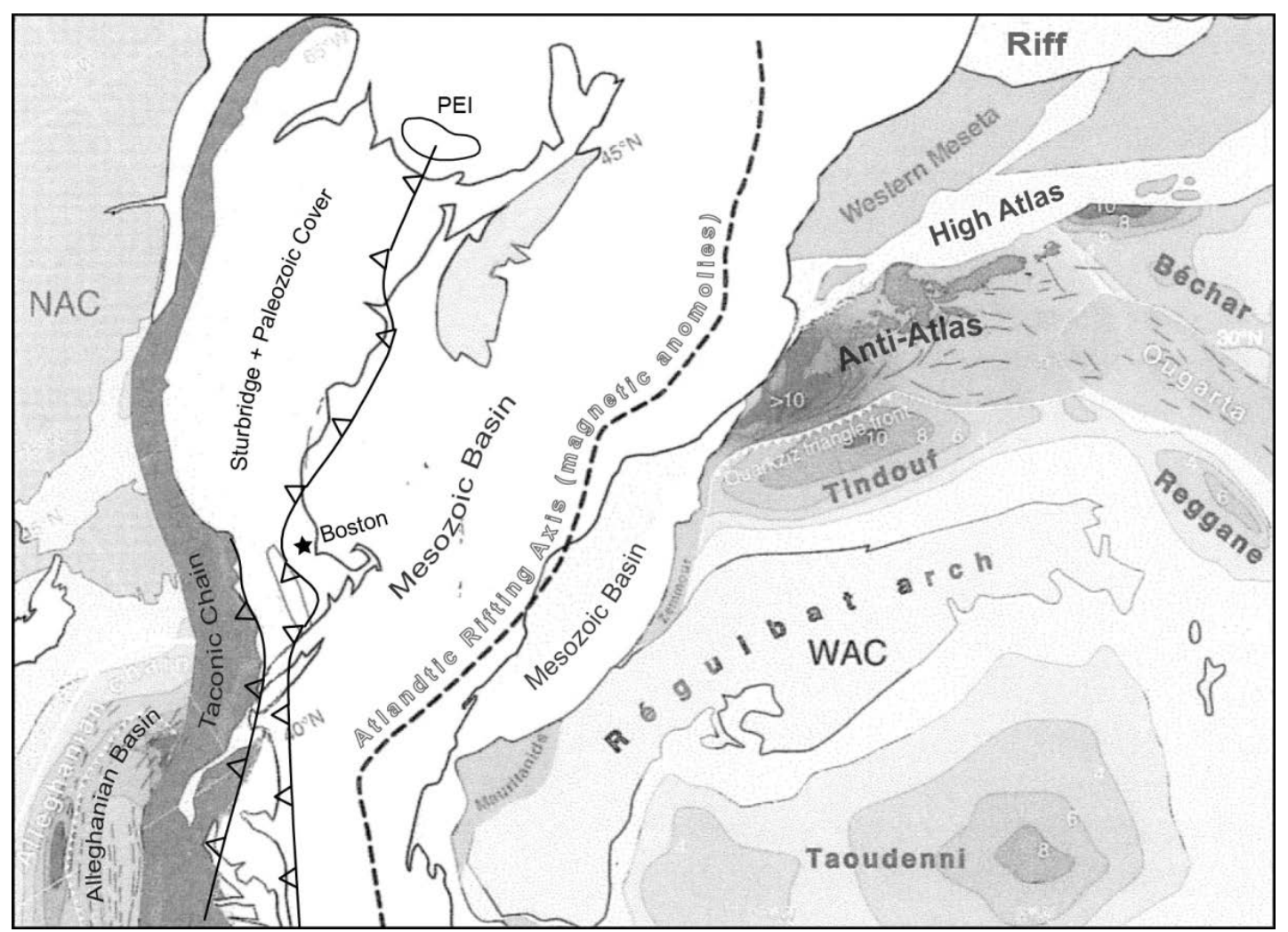

Figure 2: Map showing relation of southeastern New England with the Anti-Atlas of Morocco prior to the opening of the North Atlantic basin [modified after 39,40]. Explanation: NAC, North American Craton, WAC, West African Craton, long barbed line, Appalalchian collision zone, short barbed line, Fall Line fault zone. 
unprecedented control, detailed work and northeastward structural plunge, which reveals the deep fundamental features in the south, this region serves as the foundation for any regional analysis of the Appalachian Orogen.

It was realized by 1970 of those that followed Billings' Devonian correlation that at least some granite and metamorphosed strata near Boston were Precambrian as they were capped by Cambrian strata and that a similar situation existed on the Avalon Peninsula of eastern Newfoundland. These two areas began to be referred to collectively in the academic community as the Avalon terrane and then "Avalonia". This "Avalonia" has been used in many ways and placed differently over the years from a close to distant mini continent or islands in an ancient sea to the east, some exotic terrane or even the entire New England area in contradiction to its original intent. These lands were assumed to have docked with Laurentia usually sometime in the mid to late Paleozoic $[10,15,16]$. This echoed the earlier concept of "Appalachia" of the 1930s that was an ancient hypothetical landmass offshore of New England that later subsided. "Avalonia" and other proposed fragments are shown in various arrangements between Laurentia and ancient northwest Africa $[15,17,18]$. These proposals neglected the detailed geologic data of southeast New England that does not support the concepts. Also by 1970 it had been reestablished that the deformed terrane was pre-Silurian in age $[19,20]$.

The unraveling of the pre-Mesozoic geology of Morocco took longer. It is largely displayed in isolated areas spread across a much larger region than southeastern New England (Figure 2). Reconnaissance mapping gradually revealed the geology, but local nomenclature hindered an integration of the stratigraphy and an understanding the overall geologic history. More recently detailed geologic work and improved regional correlation, especially in the Anti-Atlas, have provided a fuller understanding of the Late Proterozoic rock and how it evolved. This now provides a good stratigraphic and tectonic framework of the Late Proterozoic that is a very close match to that of southeastern New England. This is clear in the general summaries for Morocco by Thomas et al. [21,22] and Oukassou et al. [23]. The improved age controls on both sides now allow the establishment of a firm order of events. Small differences present between the regions can be ascribed to New England being adjacent to the collision zone and suffering more deformation. Also the regions complement one another with fuller data on one side helping to fill in gaps in the other.

This paper demonstrates how the recently integrated data in the Anti-Atlas region of Morocco shows a remarkable correlation with the Late Proterozoic geologic history and lithology of southeastern New England. This firm connection solves the four important tectonic problems of how the two regions were connected, the location of the plate collision zone controlling the western Pan-African Orogeny, when the African plate become welded onto Laurentia and the mystery

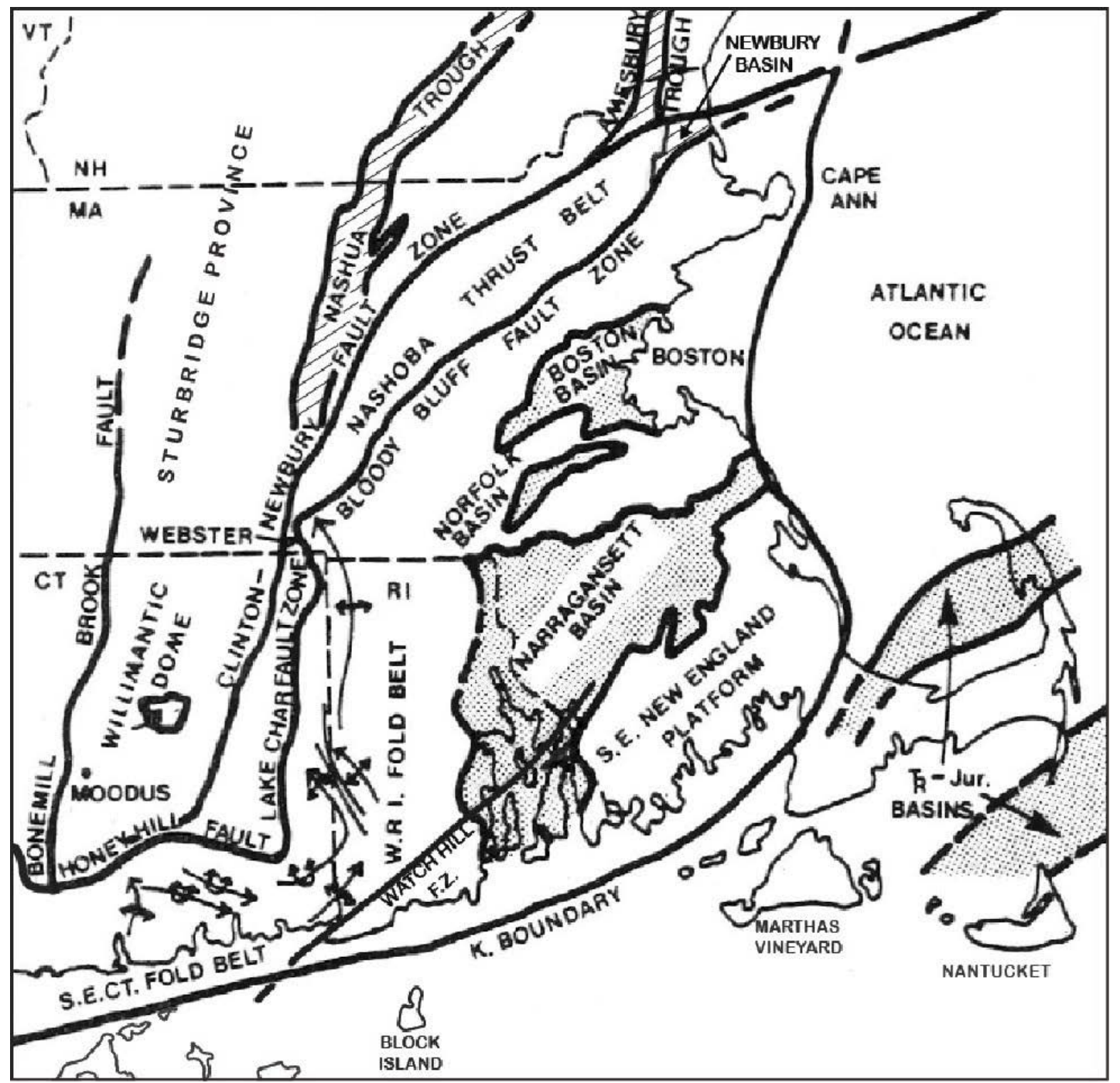

Figure 3: Map of southeastern New England showing major structural features [11,14]. The Nashoba thrust belt is the local portion of the Appalachian collision zone and the region to the southeast of it is underlain by the Late Proterozoic Southeastern New England Batholith, which is syntectonically folded along its western edge. 
of "Avalonia". The combined data demonstrate that the two regions were directly connected, the Appalachian collision zone controlled the Pan-African Orogeny, the two continental plates became connected in the Late Proterozoic and fully welded in the Late Ordovician and that there is no support for an intervening "Avalonia". Furthermore it helps clarify the history of the Iapetus Ocean.

\section{Geologic Setting}

New England and Maritime Canada were adjacent to northwestern Africa prior to the breakup of Pangea and the initiation of the Atlantic Ocean Basin during the Mesozoic (Figure 1). This break along what is now the North Atlantic Ridge occurred just east of the previous Late Proterozoic collision zone between the West African Craton and the North American Craton that had caused the western Pan-African orogeny and the closure of the early Iapetus Ocean. Southeastern New England, which had been structurally aligned with the Anti-Atlas region of Morocco, was left as a remnant of Africa that now juts out into the Atlantic Ocean (Figure 2). Rock exposed there is seen nowhere else in the U.S., as the break lies buried just offshore to the southwest and passes under mid Florida. However it is partially exposed in coastal Canada where the collision zone again comes ashore. The descriptions below are taken from Barosh and Woodhouse [24] and Thomas et al. [21,22] with additions from Oukassou et al. [23], plus further details as cited.

The collision zone is the most significant feature of the full and complex geology of southern New England. To its east lies a Late Proterozoic batholithic complex, the Southeast New England Batholith, with a fringe of metamorphosed strata, and a thick volcaniclastic sequence in the west-dipping plate collision zone, the Nashoba thrust Belt that is bordered west of the zone by a very thick wedge of Late Proterozoic metamorphosed and deformed turbidic clastic strata, the Sturbridge Province (Figure 3). The province, which formed offshore of the Middle Proterozoic Grenville Province farther west, contains some Late Proterozoic granite along thrusts and is cut by small Ordovician, Silurian and Devonian plutons. The eastern side of the Sturbridge Province also contains thrust troughs of mildly metamorphosed Cambrian? basaltic tuff and Ordovician distal turbidic siltstone and sandstone that are cut by some very late Ordovician granite. The strata west of the collision zone were deposited from the west. The Nashoba Thrust Belt, which forms the core of the collision zone, consists of a very thick sequence of metamorphosed turbidic volcaniclastic and volcanic strata that comprise the very thick Nashoba and adjacent formations. These strata, which were deposited from the east, had been scraped off the terrane to the east during the collision. These and the older strata are described in detail by Bell and Alvord [20]. The thrust belt is cut by both Late Proterozoic and Late Ordovician granite. The batholithic complex east and beneath the collision zone is chiefly composed of anatectic quartz monzonite and remnants of invaded thick littoral to shallow water quartzite, quartz schist and marble and a volcanic pile of basaltic flows, tuff and debris that had underlain the strata in the collision zone. The batholith, which has strong syntectonic flow foliation and folds near the collision zone that fade out to the east, is cut by several Late Ordovician granitic plutons plus Permian granite in the south. The Late Proterozoic granite has flow foliation but the younger granite does not. Dropped into the batholith are a series of grabens: the slightly metamorphosed latest Proterozoic Boston Basin, Carboniferous Narragansett and Norfolk Basins, the unmetamorphosed Siluro-Devonian Newbury Basin, which is mainly over the Nashoba Belt, but spills out to the east. The Siluro-Devonian strata are composed of non-metamorphosed mostly terrestrial volcanic and redbed strata. The Boston Basin fill consists of a variable sequence of terrestrial bimodal Mattapan Volcanic Complex, and coarse Roxbury Conglomerate, that grades into the marine Cambridge Argillite with an ediacaran fauna. The sequence was deposited in an active rift. Cambrian deposits cap it conformably and spill out of the basin to form remnant patches on the batholithic rock. The entire

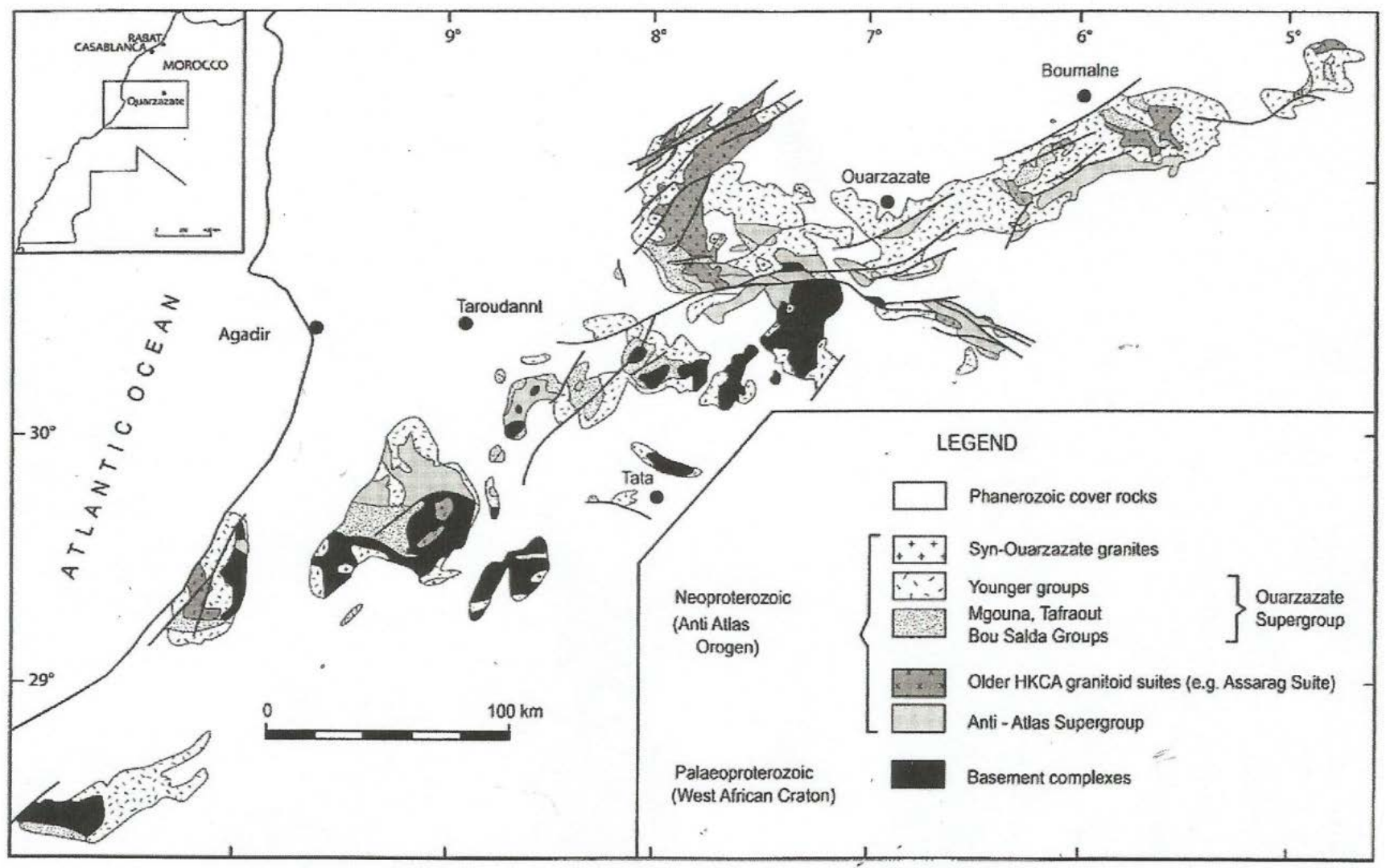

Figure 4: Stratigraphic column for the boston basin [41]. 
region has an overlay of ubiquitous Mesozoic to Holocene faults, common basalt dikes and scattered early Mesozoic grabens.

On the east side of the Atlantic Basin, Late Proterozoic rock crops out along a northeast-trending belt in the Anti-Atlas where it rests unconformably on the basement complex of the West African Craton. Here it is composed of Early Proterozoic deformed rock, but to the south the craton consists of three Archaean and Early Proterozoic metamorphic and magmatic shields [17] (Figure 4).

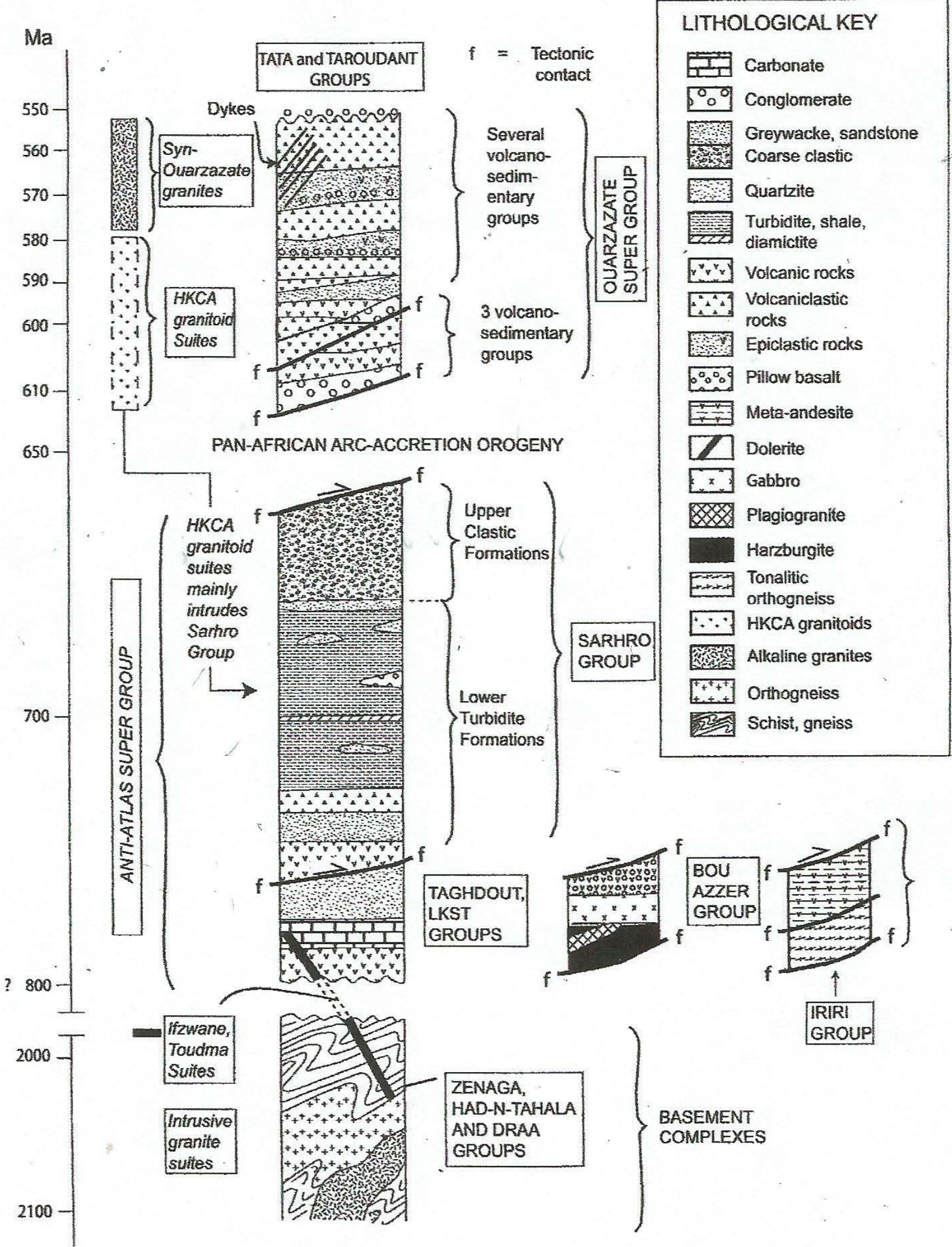

Figure 5: General geologic map of the anti-atlas orogen [22]. Explanation: HKCA, high K calc-alkaline. 
The Middle Proterozoic is absent. The overlying Late Proterozoic sequence begins with the Anti-Atlas Super group, which is made up of Taghdout and Jbel Lkst Groups of carbonate, quartzite and volcanic rock and a very thick Sarhro Group that is composed of a lower unit of turbidic shale and volcaniclastic strata, volcanic rock and some diamictite and an upper one of coarse clastic material. These were all deposited before the Pan-African Orogeny (Figure 5). Some ophiolites, the Bou Azzer Group, are present that are correlated with the lower part of the section and appear to represent sea floor material. The Supergroup strata are invaded by the older Pan African granodioritic massifs, the Assarag and Barouz granitic suites and others. The Late Proterozoic Ouarzazate Supergroup comprises a younger, post-Pan-African Orogeny unit. The supergroup consists of a variable complex of volcanic rock types, sedimentary strata and sub-volcanic granite that are the products of several interfingering volcanic complexes. It is composed mainly of thick terrestrial basalt and rhyolite, tuff, volcaniclastic beds and some pillow basalts with some coarse conglomerate. In places this material grades upward into finer sandstone and forms the beginning deposition of the later extensive molasse. These deposits form the fill of a series of narrow grabens. They are locally known as the Bou Saldo Group and in one area with very coarse conglomerate the Mgouna Group. Some conglomerate is derived from the volcanic rock below. The upper part of the Ouarzazate Supergroup unconformably overlies the lower portion and the Assarag Suite. The upper part also is cut by many synor post-granite bodies. The Ouarzazate is disconformably overlain by a sequence of carbonate, mudstone and siltstone comprising the Cambrian Tata and Taroudant Groups that contains the PrecambrianCambrian boundary within the lowermost part. This grade into the siltstone and quartzite of the Ordovician strata.

\section{Parallel Geologic Evolution of Southeastern New England and the Anti-Atlas}

The geology of New England and Morocco, described above, evolved from a sequence of Late Proterozoic events that are remarkably similar in the two regions and demonstrate a common bond with the same interpretations of the environment of deposition and tectonic setting in both regions. The combined events cited below are principally from Thomas et al. $[21,22]$ with additions from Oukassou et al. [23] for the Anti-Atlas (M), and Barosh and Woodhouse [24] for southeastern New England (NE) and apply equally, except as noted. The basic events seen both places are continental breakup, subduction and island arc formation, magmatism, uplift, graben formation and gradual transgression and overlap. There are three main divisions of contemporaneous activity spanning the Late Proterozoic to the Ordovician that apply equally to NE and M these are:

A) Pre Pan-African collision with quartzite and limestone strata of shallow water platform origin followed by a thick volcanic and turbidite sequence. This may have first developed along a quiet rifted margin followed by the formation of an island arc with increasing instability and compression.

B) Pan-African collision and subduction causing thrusting, syntectonic folding, anatectic granite, and regional metamorphism as the West African craton moved against and under Laurentia. The deformation and granite formation is greatest near the Appalachian collision zone and diminishes eastward away from it.

C) Post Pan-African collision uplift, erosion, rifting, latest Proterozoic basin filling and capping by transgressing shallow marine Paleozoic strata. The rift filling consists of volcanic and conglomeratic strata that grade laterally and upward into finer deposits, all marked by rapid facies changes during active faulting.

The differences between $\mathrm{NE}$ and $\mathrm{M}$ are surprisingly minor considering the distances separating them. These are principally proportions of lithologies due to facies changes and changes in deformation due to distance from the collision zone. The main difference is the presence in $\mathrm{M}$ of the early Late Proterozoic ophiolites, which apparently represent sea floor deposits. These are not seen in NE from being cut out by thrusting or less likely having been destroyed by later intrusion during collision.

Lesser changes within geologic divisions listed above allow them to be subdivided which leads to the seven stages of development listed below.

1. 1,000-750 Ma, Early continental break up and deposition on a passive margin, which is slightly unstable as shown by volcanic components. Taghdout and Jbel Lkst Groups passive margin shallowwater deposits of carbonate-shale, quartzite and basalt formed during an extensional event in $\mathrm{M}[17,25]$ and are cut by dikes of tholeiitic Toudma and Ifzwane Suites. The similar early quartzite strata of the Plainfield Formation and overlying marble in NE also formed in a similar depositional environment and although the dolerite intrusions are absent they do contain a basaltic volcanic complex. The shallow water sediments in the Taghdout Group contain stromatolites and would have accumulated between $\sim 1000 \mathrm{Ma}$ and $880 \mathrm{Ma}$ [26]. The Bou Azzer ophiolite, which records ocean crust formation, is present in $\mathrm{M}$. The ophiolite is dated at $760-762 \mathrm{Ma}[25,27]$ and an associated plagiogranite yields $760 \mathrm{Ma}$ [25]. This period may mark the opening of the Iapetus Ocean.

2. 750-700 Ma, Subduction was initiated and growth of a volcanic island arc occurred offshore of the craton. Deposition of thick marine volcaniclastic turbidic strata with interbedded volcanic rock of the lower part of the Iriri, Asmlil and Sarhro Groups in M and the similar thick Nashoba and bordering formations in NE occurred along the flanks of the arc. The diamictite reported in the Sarhro is almost certainly slump deposits down the flanks as they are in the Nashoba. Thomas et al. [22] consider that an island arc had developed north of the West African Craton by $\sim 750 \mathrm{Ma} .743 \mathrm{Ma}$ is recorded for a tonalite migmatite at Iriri that was likely to have formed slightly after the ocean crust near the base of the Iriri arc. The Tachakoucht gneiss of the Iriri arc represents former andesitic to dacitic porphyritic rocks crystallized about $740 \mathrm{Ma}-720 \mathrm{Ma}$ [28] or more closely $\sim 733 \mathrm{Ma}$ for the protolith [29]. Rock close to the base of the sequence in NE is dated at $\sim 730 \mathrm{Ma}$. Metagabbro of $752 \mathrm{Ma}$, augen granite gneiss of 753 $\mathrm{Ma}$, leucogranites of 705-701 Ma and metagabbro of 697 Ma in M are linked to the 750-700 Ma event in some way $[17,28,30]$.

3. 700- $640 \mathrm{Ma}$, Ocean basin shrinks with the initial Pan African Orogeny and receives the upper clastic deposits of the Sarhro Group, the orogeny is probably culminated in $\mathrm{M}$ between $\sim 680 \mathrm{Ma}$ and $\sim 660$ $\mathrm{Ma}$. The primary arc likely broke up and was intruded by hydrous arc-related magmas under medium to high-grade temperaturepressure conditions [29]. Thrusting began and the Nashoba and bordering formations were scrapped off the lower strata to the east and sliced by thrusts into the collision zone in NE. The thrusting of the ophiolite onto the rock of the arc may have started by $700 \mathrm{Ma}$ [29]. The formation of syntectonic anatectic granite along some thrust faults on the west side of the zone in NE has yielded repeated dates of between $\sim 620$ and $650 \mathrm{Ma}$ with older ones more likely, as subsequent metamorphic events tend to lessen the age. The greenschist facies deformation in $\mathrm{M}$ occurred at $\sim 650 \mathrm{Ma}$ [23], leucogneissic bands intruded into the ophiolite at $651 \mathrm{Ma}$ [28] and the Tourtit granite intruded about $651 \mathrm{Ma}$ [28]. However, ages of $\sim 663 \mathrm{Ma}$ and $\sim 654 \mathrm{Ma}$ from zircon rims of a migmatite at Iriri are interpreted to be the time of metamorphism that accompanied island arc accretion towards the craton in M. Gasquet et al. [31] combines this event and the former one to assume north-dipping subduction from $760 \mathrm{Ma}$ to $660 \mathrm{Ma}$ in $\mathrm{M}$ whereas Oukassou et al. [23] places the collision that generated the thrust sheets at $655 \mathrm{Ma}$ to $640 \mathrm{Ma}$.

4. $\sim 630-615 \mathrm{Ma}$, Ocean basin closure with deformation and formation of batholitic anatectic granite batholith as subduction continues in the main phase of the Pan-African Orogeny. Deformed with high-grade metamorphism and syntectonic folds in the Southeast 
New England Batholith near the collision zone in NE, but the flow foliation and folds fade to the east where there is only greenschist metamorphism in $\mathrm{M}$ that may have occurred earlier. In $\mathrm{M}$ there was syntectonic folding, SW-directed thrusting and emplacement of the ophiolite slivers, deformation of all the earlier Anti-Atlas Supergroup strata and emplacement of the Assarag and Bardouz granite suites at $\sim 615 \mathrm{Ma}$. There is a hiatus in the geochronological record between $660 \mathrm{Ma}$ and the time of these granites in $\mathrm{M}$. The granite appears to be late syntectonic to post tectonic, a change that could be due to either increased distance from the active edge or that granite first formed near the collision zone and spread to the east later. However, Gasquet et al. [25] considers the Pan-African orogeny to have generated abundant granite and rhyolite starting from $630 \mathrm{Ma}$ in M. A wide range of ages have been obtained in NE for the granitic batholithic complex, but $620 \mathrm{Ma}-630 \mathrm{Ma}$ is considered to be the most reliable range.

5. 615-605 Ma, End of subduction and very rapid uplift and erosion unroofs the batholith to probably build Alpine mountains in $\mathrm{NE}$ and the unroofing of the Assarag Suite of granite to provide the setting for the terrestrial grabens in NE and $\mathrm{M}$. This stripping of the cover to the level of the granite would require some time, perhaps on the order of 5 to $10 \mathrm{Ma}$. It is just such a mountain range at the end of the Proterozoic that Walcott [5] held responsible for the division between the American and European Cambrian fauna. The uplift is likely to have at least temporarily drained the reduced Iapetus Ocean to the west to allow for erosion. There are some post-tectonic granitic rocks

\section{BOSTON STRATIGRAPHIC COLUMN}

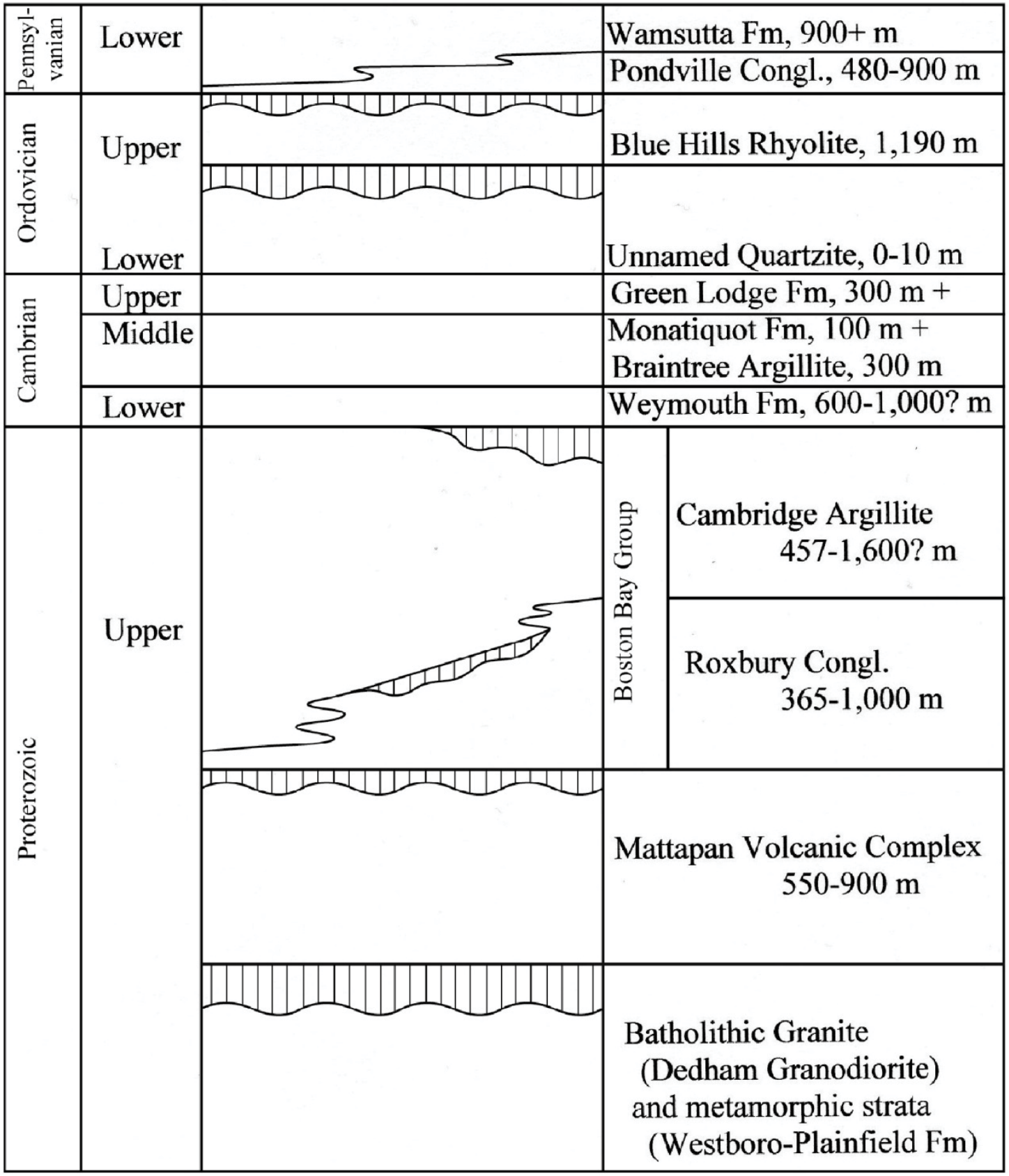

Figure 6: Generalized stratigraphic column for the anti atlas [22]. 
in $\mathrm{M}$ that range in age from 615 to $580 \mathrm{Ma}$ that either reflect episodic emplacement or part of an as yet incompletely defined continuum, perhaps rising along early normal faults beneath volcanoes.

6. 605-545 Ma, Rifting forms graben basins, probably as pullapart basins related to the start of strike-slip movement in the collision zone. The fault basins of Boston Basin, Saint John Basin in New Brunswick and those in Morocco reveal this extensional event, which extended to Egypt and vicinity where the basins of Hammamat sediment and Dokhan volcanic debris show similarities [32-35]. These basins must represent a very widespread active basin-and-range environment across a broad region. Basin filling begins with debris from volcanic centers along the active bordering faults intermixed with coarse erosional debris from the fault scarps. The deposits are characterized by rapid and complex facies changes from different bimodal volcanic centers laterally along the bordering faults as well changes downslope into the basins (Figure 6, Figure 7), making it very difficult to establish formal stratigraphic nomenclatures. The volcanic deposits in $M$ are almost all terrestrial, although they are interbedded with both subaerial and lacustrial deposits and pillow basalt is present. The volcanism and fault activity slowed with time. The deposits are very thick in the basins and pinch out at their edges. Such fill forms the Ouarzazate Supergroup in M and the Mattapan Volcanic Complex, Roxbury Conglomerate and Cambridge Argillite NE. In NE and New Brunswick the volcanic and conglomerate deposits from off the fault bluffs interfinger basinward with marine argillite containing ediacaran fauna (Figure 7). These waters represent the initial encroachment of the Rheic Sea as there is no apparent break with the later sea. There is relatively much more volcanic rock fill in $\mathrm{M}$ than $\mathrm{NE}$ and the interfingering of most coarse conglomerate may occur at the base rather than above the volcanic rock. In $M$ the fill usually grades upward into reddish molasse sandstone. Diamictite occurs at places in the sequence, in $\mathrm{M}$ it has been interpreted as tillite, but those in NE are long proven to be slump deposits and are commonly associated with slump folds that formed in an active environment. Such activity also resulted in unconformities within the section. Some younger granitic suites, $2575 \mathrm{Ma}-545 \mathrm{Ma}$, cut the fill in $\mathrm{M}$, but this is not seen in NE, although the lower, volcanic part of the fill is cut by basaltic intrusions and sills. Also, the extensive basic dike system that cuts the rock in $\mathrm{M}$ is delayed until the Cambrian in NE. The most reliable date of the oldest known basal volcanic rock in $\mathrm{NE}$ is $\sim 602 \mathrm{Ma}$, but different types of dating on the same rock gives a range of 459 to $605 \mathrm{Ma}$, several younger dates are from the strata above and the Cambridge Argillite contains an ediacaran fauna. The basal part of the Ouarzazate Supergroup, the Bou Saldar Group, was deposited $\sim 605 \mathrm{Ma}$ and continued to $\sim 580 \mathrm{Ma}$ and the higher rhyolite and granitic rock in the supergroup is dated between 581 and 543 $\mathrm{Ma}[31,36]$. Oukassou et al. [23] show the range as $\sim 580 \mathrm{Ma}$ to $\sim 545$ Ma for the Supergroup and the transition to the Cambrian at 542 Ma. The deposition in the basins continued to almost the end of the Proterozoic as the activity decreased.

7. Early Cambrian-Early Ordovician, The Rheic Sea fills and overtops the basins to transgress across a slowly subsiding region. The strata appear conformable within basins and unconformable outside of them. The sedimentation in NE appears continuous across the time boundary as it does in M. In M the division lies within the Tata and Taroudant Groups a short distance above a disconformity at the top of the Ouarzazate Supergroup [37]. The deposits consist of argillite, limestone and sandstone in the Cambrian Tata and Taroudant Groups in $\mathrm{M}$ and in the Weymouth, Braintree, Monatiquot and Green Lodge Formations in NE, but there is relatively more carbonate strata in $\mathrm{M}$. The Ordovician consists of siltstone and sandstone deposits in $\mathrm{M}$ and apparently predominantly quartzite in NE, although the siltstone component may have been eroded.

After the Early Ordovician the geologic features were of a more local nature and cross Atlantic correlations less obvious until the Mesozoic. During the Ordovician subsidence to the west of the collision zone in New England reconstituted the Iapetus Ocean. Near the end of the period subduction was renewed to first form an oceanic trench on the west side of the collision zone and then close it to terminate the ocean and weld the Laurentian and African plates together, with granite crossing the boundary. This, the Taconic Orogeny, caused renewed thrusting and emplacement of granite in the collision zone, built large volcanoes, which were underpinned

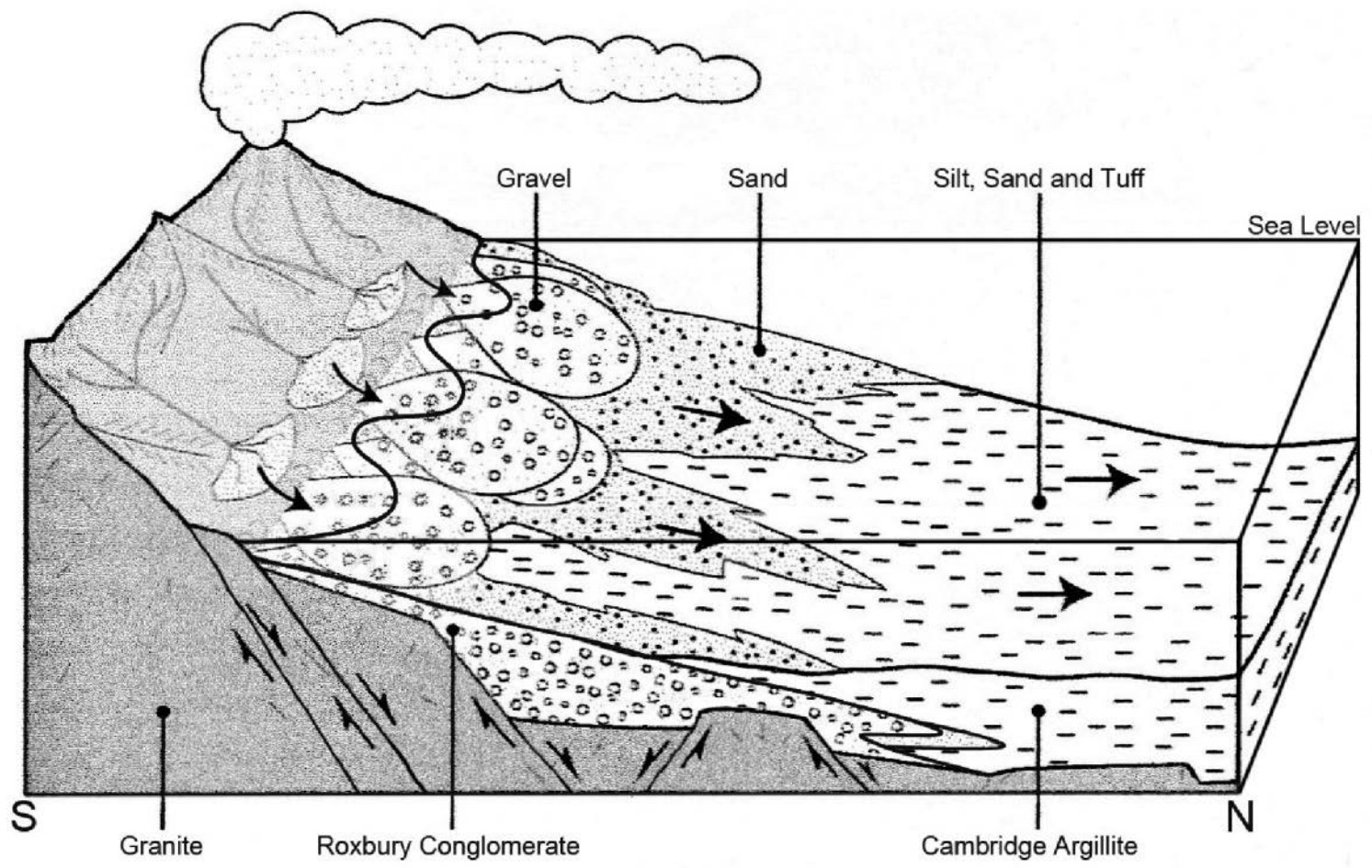

Figure 7: Depositional environment for the boston basin [41]. 
by large granite bodies, on both the north and south borders of the Boston Basin, and caused greenschist metamorphism in the basin rock. When subduction ceased the region quickly rose, was eroded and a long, mostly terrestrial volcanic chain was built up along the collision zone and adjacent areas beginning in the Early Silurian and continuing through the Devonian. The effects of these events, which were much less than the Pan-African ones apparently decreased rapidly to the east and there is no clear record of them in Morocco, although the finer marine deposits found east of the volcanic chain in Nova Scotia may find a match in the quieter conditions that prevailed in Morocco where there was uninterrupted deposition of finer material that continued into the Silurian and Devonian [34].

\section{Discussion and Conclusion}

The closely matching geology demonstrated from recent independent descriptions from both sides of the Atlantic Basin demonstrates a close connection of southeastern New England and the Anti-Atlas of Morocco during the Late Proterozoic to the Ordovician. They both were affected by plate break up (800-700 Ma), subduction and island arc formation (750-700 Ma), deformation (700-640 Ma) and intrusion during the Pan-African Orogeny (630$615 \mathrm{Ma}$ ), uplift (615-605 Ma), rifting (605-545 Ma) and transgression by a Cambrian to Ordovician sea. These events, along with a last gasp of subduction at the end of the Ordovician record an entire cycle of continental break up to collision and plate reassembly that covers the Iapetus Ocean from birth to death and the initial encroachment of the Rheic Sea.

The collision zone that formed as the ancient African plate moved relatively westward and under Laurentia now snakes across southeastern New England, where it is well exposed. The rifting of the composite plate in the Mesozoic broke just east of this zone and left southeast New England dangling on the west side of the Atlantic Basin. However, the geology in New England retains a detailed record of the parallel events that occurred during the ancient connection in the previously aligned Anti-Atlas region of Morocco (Figure 2). The match in deformation, lithology and timing of the Pan-African Orogeny and the development of the grabens in the latest Proterozoic pins down the connection. The development of these grabens, which formed a basin-and-range topography, and the history of their filling is a unique occurrence on both sides of the Atlantic Basin that clearly demonstrates that New England and Morocco were joined at that time. This connection also demonstrates that the Appalachian collision zone exposed in southeastern New England controlled the Pan-African Orogeny of ancient northwestern Africa. The PanAfrican Orogeny peaked about 620-630 Ma caused strong flow foliation, syntectonic folding and high-grade metamorphism in and adjacent to anatectic batholithic granite near the collision zone with this deformation diminishing eastward to greenschist-grade in the Anti-Atlas. Such an early closure of the Iapetus Ocean eliminates both a place and a reason for any intervening hypothetical Paleozoic land such as "Avalonia".

\section{Acknowledgements}

The author gratefully acknowledges the support, data and aid received over the years by the personnel of the Boston Office of the U.S. Geological Survey, especially MH Pease Jr, the New England Seismotectonic Study sponsored by the U.S. Nuclear Regulatory Commission, Boston College, the geologic consulting community of southern New England, Association of Engineering and Environmental Geologists and the Massachusetts Geological Survey. The use of the excellent engineering studies in southern New England made over the past 150 years also is acknowledged.

\section{References}

1. Lyell C (1845) Geological map of the United States, Canada \& C. John Murray, London, scale 1:3,928,320.
2. Billings MP (1956) The geology of New Hampshire. Part II, Bedrock geology / Marland P. Billings. New Hampshire State Planning Development Commission, Concord, $\mathrm{NH}, 203$.

3. Hatcher RD Jr (2002) Alleghanian (Appalachian) orogeny, a product of zipper tectonics: Rotational transpressive continent-continent collision and closing of an ancient oceans along irregular margins. Geological Society of America Special Paper 364: 199-208.

4. Hatcher RD Jr, Martinez Catalan JR, Arenas R, Díaz García F, et al (2002) Variscan-Appalachian dynamics: The building of the late Paleozoic basement. Geological Society of America Special Paper 364: 199-208.

5. Hatcher RD Jr (2010) The Appalachian orogen: a Brief summary.

6. Tollo RP, Bartholomew MJ, Hibbard JP, Karabinos PM (2010) From Rodinia to Pangea: the lithotectonic record of the Appalachian region. Geological Society of America Memoir 206: 1-19.

7. Walcott CD (1891) The North American continent during Cambrian time: U.S. Geological Survey, Twelfth Annual Report 523-568.

8. Wilson JT (1966) Did the Atlantic close and then re-open? Nature 211: 676681.

9. Barosh PJ, Fahey RJ, Pease MH Jr (1977) Preliminary compilation of the bedrock geology of the land area of the Boston 2 degree sheet, Massachusetts, Connecticut, Rhode Island and New Hampshire. U.S. Geological Survey, Open-File Report 77-285.

10. Kaye CA, Zartman RE (1980) A Late Proterozoic $Z$ to Cambrian age for the stratified rocks of the Boston Basin, Massachusetts, USA, Virginia Polytechnic Institute and State University, Department of Geological Sciences, Memoir 2: 257-264.

11. Barosh PJ, Hermes OD (1981) Guidebook to geologic field studies in Rhode Island and adjacent areas: The 73rd Annual Meeting of the New England Intercollegiate Geologic Conference.

12. O'Brian SJ, Wardle RJ, King AF (1983) The Avalon Zone: a Pan-African terrane in the Appalachian Orogen of Canada: Geological Journal 18: 195222

13. Barosh PJ (1984) Regional geology and tectonic history of southeastern New England. In: Hanson LS, Geology of the coastal lowlands from Boston, MA to Kennebunk, ME. 76th Annual New England Intercollegiate Geologic Conference, Salem State College, MA 1-35.

14. Barosh PJ (1991) Regional geologic setting of Boston. In: Woodhouse D, Barosh PJ, Geology of Boston, Association of Engineering Geologists, Bulletin, Massachusetts, U.S.A 28: 386-408.

15. Barosh PJ (2005) Bedrock geologic map of the Oxford quadrangle, Worcester County Massachusetts, Providence County Rhode Island, and Windham County Connecticut. Massachusetts Geological Survey (4th), scale 1:24,000.

16. Barosh PJ (2013) Regional geologic setting for the Boston Area: Civil Engineering Practice. Journal of the Boston Society of Civil Engineers 27: 41-99.

17. Nance RD, Linnemann U (2008) The Rheic Ocean: origin, evolution, and significance. GSA today 18: 4-12.

18. Murphy JB (2007) Geological evolution of middle to late Paleozoic rocks in the Avalon terrane of northern mainland Nova Scotia, Canadian Appalalchians: a record of tectonothermal activity along the northern margin of the Rheic ocean in the Appapachian-Caledonide orogen. GSA Special Paper 423: 413435.

19. Ennih N, Liegeois, JP (2008) The boundaries of the West African craton, with special reference to the basement of the Moroccan metacratonic Anti-Atlas belt. Geological Society of London, Special Publication 297: 1-17.

20. Stampfli GM, Hochard C, Verard C, Wilhem C, von Raumer J (2013) The formation of Pangea. Tectonophysics 593: 1-19.

21. Page LR (1976) Contributions to the stratigraphy of New England. Geological Society of America, Memoir 148445.

22. Bell KG, Alvord DC (1976) Pre-Silurian stratigraphy of northeastern Massachusetts. In: Page LR, Contributions to the stratigraphy of New England. Geological Society of America, Memoir 148: 179-216.

23. Thomas RJ, Chevallier LP, Gresse PG, Harmer RE, Eglington BM, et al. (2002) Precambrian evolution of the Sirwa Window, Anti-Atlas Orogen, Morocco. Precambrian Research 118: 1-57.

24. Thomas RJ, Fekkak A, Ennih N, Errami E, Loughlin SC, et al. (2004) A new lithostratigraphic framework for the Anti-Atlas Orogen, Morocco. Journal of African Earth Sciences 39: 217-226.

25. Oukassou M, Hadi El Hadi, Haisen F, Saber N (2015) Central Anti- Atlas traverse, the northern border of the West African Craton. Sociedad Geologica 
de Espana, Comision de Petrologia, Geolquimica y Geocronologis de rocas igneas y metamorficas, Field trip guidebook, Iberian-Moroccan Annual Meeting Field trip 68.

26. Barosh PJ, Woodhouse D (2012) A city upon a hill: the geology of the city of Boston \& surrounding region: Civil Engineering Practice. Journal of the Boston Society of Civil Engineers 480.

27. Admou H, Samson S, Essafi A, Wafik A (2002) A new datation at 760 Ma of the plagiogranites associated to the Neoproterozoic Bou-Azzer and Siroua ophiolite (Anti-Atlas, Morocco). Abstract 19th Coll. African Geology, El Jadida, Morocco 4-5.

28. Bouougri $\mathrm{EH}$, Saquaque A (2004) Lithostratigraphic framework and correlation of the Neoproterozoic northern West African craton passive margin sequence (Siroua-Zenaga- Bouazzer Elgraara Inliers, Central Anti-Atlas, Morocco): an integrated approach. Journal of African Earth Sciences 39: 227-238.

29. Samson SD, Inglis JD, D'Lemos RS, Admou H, Blichert-Toft J, et al. (2004) Geochronogical geochemical, and $\mathrm{Nd}-\mathrm{Hf}$ isotopic constraints on the orign of Neoproterozoic plagiogranites in the Tasriwine ophiolite, Anti-Atlas orogen, Morocco. Precambrian Research 135: 133-147.

30. Triantafyllou A, Berger J, Baele J-M, Bruguier O, Diot H, et al. (2015) The Tachakoucht-Iriri-Tourtit arc complex (Moroccan Anti-Atlas) Neoproterozoic records of polyphased subduction-accretion dynamics during the Pan-African orogeny. Journal of Geodynamics 96: 81-103.

31. Triantafyllou A, Berger J, Baele J-M, Diot H, Ennih N, et al. (2015) Neoproterozoic oceanic are remnants in the Moroccan Anti-Atlas: reconstructing deep to shallow arc custal sequence and tracking Pan-African subduction-accretion processes. Geophysical Research Abstracts 17.

32. D'Lemos RS, Inglis JD, Samson SD (2006) A newly discovered orogenic event in Morocco: Neoproterozoic ages for supposed Eburnean basement of the Bou Azzer inlier, Anti-Atlas mountains: Precambrian Research 147 65-76.

33. Gasquet D, Ennih N, Liegeois J-P, Soulaimani A, Baidder L (2008) The PanAfrican belt. In: Michard A, Saddiqi O, Chalouan A, Frizon de Lamotte D, Conltinental evolution: the geology of Morocco. Springer Science 33-64.
34. Willis KM, Stern RJ, Clauer N (1988) Age and geochemistry of Late Precambrian sediments of the Hammamat series from the northeastern desert of Egypt. Precambrian Research 42: 173-187.

35. Eliwa H, Breitkreuz C, Khalaf I, Gameel KH (2010) Depositional types of Early Ediacaran terrestrial volcanosedimentary succession in Gebel El Urf area, North Eastern Desert, Egypt. Journal of African Earth Sciences 57: 328-344.

36. Helg U, Burkhard M, Caritg S, Robert-Charrue C (2004) Folding and inversion tectonics in the Anti-Atlas of Morocco. Tectonics 23: 1-17.

37. Zimmermann J (2008) Megaconglomerates of the Pan-african orogeny - intramontane-freshwater-basin-deposits? With special emphasis to the Central Destert, Egypt. Freiberg Technische Universitat, Oberseminar Geologie Thema 10.

38. Gasquet D, Levresse G, Cheilletz A, Azizi-Samir MR, Mouttaqi A (2005) Contribution to a geodynamic reconstruction of the Anti-Atlas (Morocco) during Pan-African times with the emphasis on inversion tectonics and metallogenic activity at the Precambrian-Cambrian transition. Precambrian Research 140: 157-182.

39. Landing E, Bowring SA, Davidek KL, Westrop SR, Geyer G, et al. (1998) Duration of the Early Cambrian: U-Pb ages of volcanic ashes from Avalon and Gondwana. Canadian Journal Earth Science 35: 329-338.

40. Stacy FD (1977) Physics of the Earth. John Wiley \& sons, New York, 414.

41. Burkhard M, Caritg S, Helg U, Robert-Charrue C, Soulaimani A (2006) Tectonics of the Anti-Atlas of Morocco. Comptes Rendus Geosciences 338: 11-24.

42. Barosh PJ, Woodhouse D (2013) Settlement, topography \& geologic studies of Boston: Civil Engineering Practice. Journal of the Boston Society of Civil Engineers 26 \& 27: 9-40.

43. Barosh PJ, Woodhouse D (2013) Geology of the Boston Basin: Civil Engineering Practice. Journal of the Boston Society of Civil engineers 26 \& 27: $100-236$. 